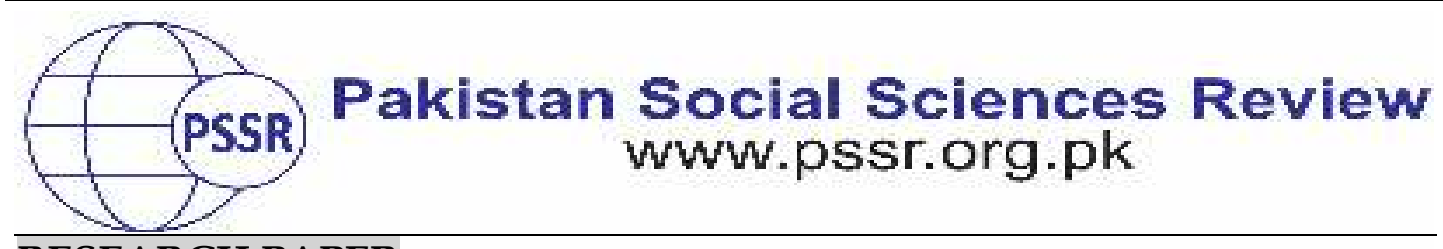

RESEARCH PAPER

\title{
Ideology, Politics and Media: A Critical Discourse Analysis of New Headline about Pakistan Democratic Movement
}

\author{
Fareeha Butool*1 $^{* 1}$ Dr. Musarrat Azher ${ }^{2}$ Faheem Arshad ${ }^{3}$
}

1. M. Phil Scholar, Department of English, University of Sargodha, Punjab, Pakistan

2. Assistant Professor, Department of English, University of Sargodha, Punjab, Pakistan

3. Lecturer, Department of English, University of Sargodha, Punjab, Pakistan

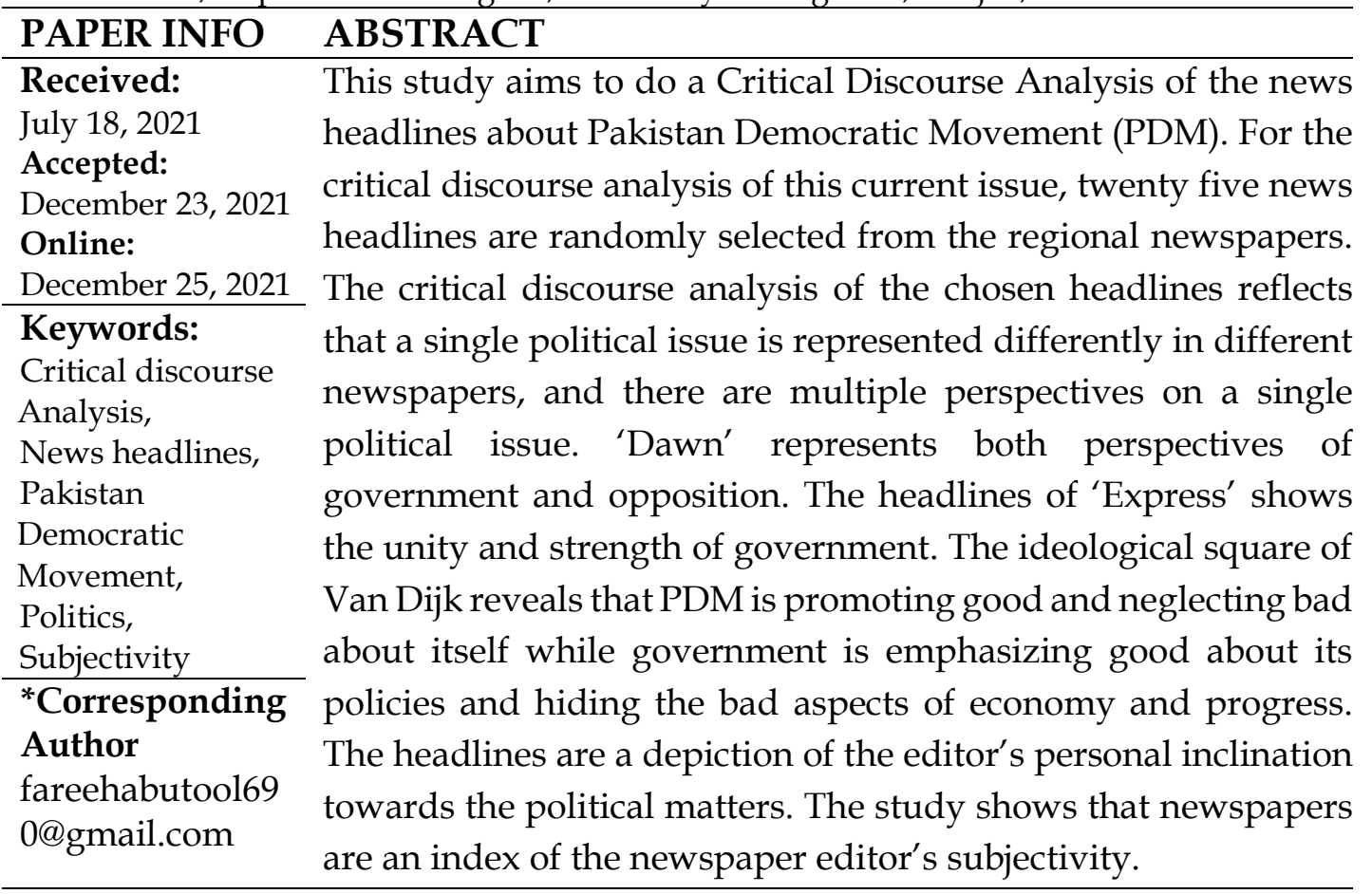

\section{Introduction}

At the beginning of the twentieth century, the emergence of technologies and discoveries turned this world into a bustling place. The emergence of modernism shows the rapid spread of information utilizing media. In recent last two decades, the value of media has been even more enhanced. Media is a means of conveying information and a source of communication. It is a fact that we live in an era governed by media, and we all are under the unconscious hegemony of media. Media builds new ideologies and transforms the already established beliefs and ideologies it is so because media has the power to manipulate the affairs on its own, and most of the time, simple issues are made complex. Today, it is evident that media is not only shaping ideologies. Instead, it is building the truth through its means and schedule. That is why it has become an inevitable pillar of society. There is no denying that 
media plays with the words, and the nature of delicate issues is made worse when media plays with the words. The importance of media in twenty-first century is doubled because of the immense globalization and the shift of worldly affairs from traditional means to online ones. One of the media parts is a newspaper, and within the newspaper, an essential part is headlines. Newspaper headlines are a reflection of the current economic, political and social situation of any region. News headlines are an indispensable element of a newspaper because they provide a quick overall idea of what is going on. This attracts people who do not have that much time to read the news's complete details; headlines serve the purpose for them by giving them the idea of the current stories and issues in no time.

Pakistan is a land earned on political upheavals, and those political turmoil continue to date. The political diversity of Pakistan results in the emergence of various political parties. The party that is governing right now is Pakistan Tehreeke-Insaf (PTI). PTI, led by Imran Khan, is subjected to serious allegations of the joint movement of opposition parties. Pakistan Tehreek-e-Insaf won the 2018 elections for the first time since it emerged on the political horizon. Since its first famous victory, PTI has been caught in a tornado in which it is continuously circling against the opposition's objections. Recently the opposition parties jointly started a rigorous movement against the policies of the government. The joint political action is called Pakistan Democratic Movement (PDM), formally launched on August 14, 2020. The parties that are part of this movement are Pakistan People's Party (PPP), Pakistan Muslim League Noon (PMLN). The policies of the government are declared harmful to the national cause. The movement intends to overthrow the elected government by spreading awareness among the public.

On the other hand, the government is firm on completing its five-year tenure declared according to the constitution. The cabinet ministers believe that the so-called PDM must first look into the mirror before pointing figures to the lawfully elected government. The government of Pakistan aims to retaliate against the foul strategies of PDM.

\section{Literature Review}

Critical Discourse is followed by multiple researchers for the interpretation and analysis of the political and power affairs and the formation and development of ideologies. According to Hall (1973), the news does not report all the incidents that occur from dawn today in everyday life. Rather it represents a small portion of those millions of incidents that take place in a single day.

Van Dijk's model of examining the ideologies is applied by Pasha (2011) to explore the representation of Islamic doctrines in the Egyptian newspapers. Pasha applies the ideological square of Van Dijk to see what good aspects of Islam are 
emphasized and how the negative or bad portrayal of Islam is de-emphasized or avoided by the newspapers. Bilal et al. (2012) applied the CDA to examine the ideology used in TV talk shows Discourse.

\section{Critical Discourse Analysis}

Critical Discourse Analysis (CDA) is the close examination of discursive political and power ideologies in linguistic studies. It is the most followed strategy for analyzing political issues and current affairs. According to Fairclough (1993), the primary aim of

CDA highlights the hidden realities and ideologies embedded in power relations and political discourse.

\section{Material and Methods}

The data for this research study has been taken from ten different local newspapers of Pakistani media. The headlines are gathered randomly from the leading Pakistani newspaper from September 20, 2020, to May 2, 2021. The study aims to investigate the representation of a single political movement, PDM, in different newspapers. For this purpose, Van Dijk's model of discourses analysis is applied to know the nature and representation of a text in media. The 'Theory of Ideology' and 'Ideological Square' is used to understand how politics and power construct the general public's mind.

\section{Critical Discourse Analysis}

Critical Discourse Analysis (CDA) is an emerging domain of linguistic studies, and it is the most followed strategy for analyzing political issues and current affairs. The fundamental aim of CDA is to highlight the hidden realities and ideologies embedded in power relations. (Fairclough, 1993). Critical discourse analysis is an emerging and rapidly growing approach to research. Critical Discourse analysis emerged in the early 1990s and is marked by the famous journal Discourse and Society launched by Van Dijk in 1990. The primary concern and ultimate objective of Critical Discourse Analysis are to analyze and examine 'language as a social practice' (Fairclough and Wodak, 1997), which implies that language is dependent upon the context and is used according to the particular context. CDA is widely used in political studies not to examine the surface ideologies but to see the hidden truths and unexplained beliefs. (Lakoff, 1987). Fairclough (1989) puts forward the model of CDA that comprises three procedures; the object under examination or analysis, the way of production and reception of that object by humans, and the sociopolitical conditions and historical circumstances which controls these procedures. 
According to Van Dijk (1998), ideologies are the 'worldviews' that construct an individual's cognition in society. In this way, CDA has become a research tool and most followed methodology to investigate the political use of "power' and reveal the ground of "ideologies." Van Dijk (1998) examines media as the primary stimulus behind the usage and interpretation of language because the significant aim of media is to study the language used in political discourse, power talk, ideologies.

\section{Ideological Square by Van Dijk}

Van Dijk (2000) developed a framework for ideological analysis, which comprised four elementary principles. The four basic tenets combine to form the ideological square. The principles of the ideological square are,

1. To emphasize the good things about Us

2. To de-emphasize the bad things about Us

3. To highlight the bad things about Others (Them)

4. To de-emphasize the good things about Others (Them)

This ideological square is used in this study to evaluate the political rift between the Pakistan Democratic Movement (PDM) and the Pakistan Tehreek-eInsaf (PTI) government. The mindset of different newspapers is also revealed using the ideological square of Van Dijk to know whether the famous newspapers support the government or take the side of the opposition movement as it is seen that certain newspapers consistently report in favour of the government. In contrast, some of the newspapers strongly support the opposition movement started by PDM.

\section{Pakistan Democratic Movement (PDM)}

The policies of the government are declared harmful to the national cause. The movement intends to overthrow the elected government by spreading awareness among the public, Pakistan Tehreek-e-Insaf. The trend is formed up of eleven opposition parties most significant of them are Pakistan Muslim League (N), Pakistan Peoples Party and Jamiat Ulema-e-Islam. PDM was founded on September 20, 2020, which an aim to demolish the government. The central slogan of PDM is to give honour, respect and support to vote (vote ko izzat do). After its formal establishment on September 20, 2020, at the Islamabad, PDM participated, rallied, and numerous conferences to derail the government. The first protest was held in Gujranwala on October 16, 2020, which various newspapers claimed to be a powerful show. 


\section{Data Analysis}

Based on the structure of headlines, they are divided into plain headlines and pointer headlines. In section A of data analysis, headlines are interpreted, while in section $\mathrm{B}$, the ideology of PDM and government is interpreted concerning the selected news headlines.

Section A: Interpretation of Headlines:

\section{News Headlines}

Pakistan's united opposition protests against Imran Khan's rule. (The Guardian October 17, 2020)

This newspaper represents the primary agenda and the fundamental goal of PDM against the PTI government. The word 'united' is used in the headline to represent the alignment of almost all opposition parties of Pakistan against the government. The word 'united' reflects PDM parties' unanimous policies and joint strategies to de thorn Imran Khan from his seat. The term 'rule' makes the news ambiguous because using 'government' or 'elected government' would have been more appropriate. Still, here it seems that this newspaper is focusing more on PDM by emphasizing its notion and less on the government as it is de-emphasizing the status of the government.

\section{Opposition moot to devise anti-govt strategy today (Dawn September 20, 2020)}

This headline shows the strategy of PDM against the government. The headline indicates that PDM (opposition) is determined to overthrow Imran Khan's government by devising anti-govt strategies. The word 'moot' suggests that the opposition is not sleeping. Instead, it is having open debates and discussions to formulate effective plans against the government. The possible actions and ways of PDM are highlighted from the phrase 'anti-govt strategy', which means that there will be no agreement of PDM with govt on any cost and opposition is united only to uproot the government for which it is devising anti-govt policies.

People won't pay heed to PDM protest plans: PM (Dawn January 2, 2021)

Here the headline is produced by the leading English Newspaper of Pakistan. Prime Minister, Imran Khan, uses the word people that includes all the general public of Pakistan. The word people is used to avoid any biases and to call everyone for health safety. This newspaper gives us a hint that by these words of PM Imran Khan, not more public would be gathering at the protest place, but in the following newspaper's headline, the term "power show is used to show the huge turnout of the public on the protest call of PDM. Furthermore, Imran Khan has used the word 'plans' 
which reflects that PDM lacks strength as there is not an ultimate step of protesting against the government; instead, it's a plan.

PDM demands PTI got quit by January 31 or face long march (Dawn December 14,

Here the stance of PDM looks solid and coherent as it "demands' the resignation of Imran Khan, declaring him incapable of handling the government. The linguistic structure of this headline shows that PDM is giving an open warning to the government to either quit the government or face them openly, which indicates that it is getting better and intense and is declaring its future strategy against the government.

My narrative is the same as Quaid-i-Azam's, says Nawaz at PDM's Lahore power show. (Dawn December 14, 2020)

Here the word 'Quaid-e-Azam' is essential as the President because the former President of PLM (N) uses it to compare his narrative about the current government and the overall situation of Pakistan. Nawaz Sharif is putting himself on similar grounds to Quaid-e-Azam to present his concern for the nation. And emphasize that the PTI government is not the right to achieve the destination we long for; instead, it is PDM that would lead the country towards the successful accomplishment of the goal. The second word used in this headline is "power show' which means that PDM is not lagging in its quest to derail the government. The term "power show' reflects the strength and political scope of PDM.

PDM leaders vow to hold Lahore rally despite got warnings. (Dawn December 7,

The commitment and steadfastness of PDM are reflected in word vow'. This headline manifests the manifesto of PDM to fight against the corrupted and abnormal system of the PTI government. The unity of PDM is also reflected in the phrase 'PDM leaders', which confirms the agreement of leaders of eleven opposition parties on one page against the PTI government. The word 'warnings' indicates the policy of PDM to move on while ignoring the consecutive warnings given by the government. This headline indirectly hints towards the progress of PDM despite the government.

PDM playing "reckless" politics with people's safety amidst COVID surge: PM (The Nation November 21, 2020)

DG ISPR uses the expression of 'chai-pani' to show the only entertainment and support PDM will get military is tea which also hints at an informal interaction. The legal issue of targeting the elected democratic government of Pakistan is not 
going to be discussed within the military spheres of Pakistan. DG ISPR is clearly putting forward the stance of the military in front of stubborn PDM leaders. $21,2020)$

'PDM has its own interest: Sherani (Daily Balochistan Express Quetta December

This news headline presents the notion of Maulana Muhammad Khan Sherani, which indicates the inner conflicts within the PDM. According to Sherani, every party in PDM has its political interest for which it is striving; on the whole, there is no united plan or aim. The name PDM is given to the personal political pursuits of each party within PDM. The phrase 'own interest' shows the internal conflicts of PDM and the political desire present behind the so-called national motive claimed by it.

Opposition staging 'drama' to get NRO (The Express Tribune December 18, 2020)

This headline reflects the notion of Murad Saeed towards the opposition movement of PDM. He declares the political progress of PDM useless as its plan is nothing but merely a drama in front of the government. Murad Saeed uses the word 'drama' to indicate the non-serious movement. This news headline also reflects the possible implicit ideology of PDM, which is to get an escape from the judicial inquiries going against the leading leaders of PDM. The word 'staging' also makes the political movement ambiguous as it seems that the PDM is having its subjective matters over the general public of Pakistan.

No let-up in agitation till PTI govt's ouster: PDM (Dawn December 24, 2020)

This news headline shows that the stance of PDM regarding Imran Khan's govt is ultimate and robust as it uses the word 'no', which means there is no other option for the government but to leave. The term 'ouster' shows the most wanted expulsion of government by PDM, as the only plan of PDM is to get Imran Khan out of his office and take all the reins into its own hands. This headline emphasizes the primary goal of PDM for which it was established. 21, 2020)

War of words erupts after govt refuses permission for PDM Rally (Dawn November

The political Cold War between the government and the political movement of PDM is highlighted in this headline. The phrase 'war of words' predicts the actual rift and tension between the government and PDM as the leaders and ministers from both sides are targeting each other in press conferences and media talks. The word 'erupts' clarifies the political outburst and severity of PDM against the refusal of government. On the other hand, the government strategy is also expressed in this 
headline, as the government is not ready to allow PDM for rallies and protests at any cost. The newspaper manifests the agitated reaction of PDM against this action of the government.

\section{PDM takes anti-PTI protest to ECP office (Dawn January 20, 2021)}

The primary aim of PDM is again highlighted in this headline as PDM extends its reach to the Election Commission of Pakistan (ECP). The protest of PDM indicates the warnings for the government as it strengthens the political access and position of PDM against the government. This newspaper uses the word 'anti-PTI' rather than the usually used expression 'anti-govt by the majority of the newspapers. 'Anti-PTI' indicates the political disgust and agitation of PDM against the PTI party, which means that the war of PDM is not against the government but against the currently governing party.

\section{PDM to abstain from NA session today (Dawn March 6, 2021)}

This news headline reflects the avoidance of PDM from entering the National Assembly to attend the session. The notion of PDM to stand and fight for the sake of the general public is denied in this headline as PDM is itself is not ready to face the government. The word 'abstain' shows the deliberate avoidance of PDM to ignore the National Assembly session. The CDA analysis implicitly elaborates that PDM is not coherent in its stance to represent the problems of the general public of Pakistan. Instead, it is oscillating in confusion and avoiding the NA sessions to stay away from the political responsibilities it owns.

\section{Opposition asks PM to resign with honour (Dawn March 4, 2021)}

The first and foremost demand of PDM is reflected in this news headline which is the resignation of Imran Khan from the seat of Prime Minister. The phrase 'resign with honour' represents the demand of PDM humbly and politely to Imran Khan for his resignation. This phrase implicitly conveys the other means which PDM can use for the resignation if Imran Khan does not resign with honour. Secondly, 'resign with honour' is the goal of PDM, for which it will go to any extent if Imran Khan does not give in.

Setback for PDM as Zardari snubs Sharifs on resignations (Dawn March 17, 2021)

PDM is a joint political movement of eleven political parties, and its unity is under severe objections of government and media because it seems there is something wrong within the PDM as its headline indicates the internal conflicts and clashes between leading opposition parties of PDM named as PPP and PML (N). The internal conflicts of PDM provide a suitable environment for the government to mock PDM, as Shibli Faraz highlights the political setback to this movement, which is a 
result of PPP's leadership finding faults in the PML $(\mathrm{N})$ leaders. The strategy adopted by PDM to turn the parliamentary tables was to reign from NA and disturb the quorum of the house. Still, to the great disappointment of PML (N), PPP steps back from resigning, and it provides a suitable situation for the government to hit the nail. The internal matters seem uncontrollable, and PDM seems puzzled.

'United' PDM to craft new charter on 14th (The Express Tribune November 9,

This news headline indicates the upcoming meeting of PDM to reach a consensus on the plans and policies against govt. The word 'united' is used sarcastically to show the individuality present in PDM, which indicates that PDM is united anymore. Rather, it is divided on multiple issues, and this joint opposition is now restricted to a one-sided agenda. To gain the previous strength and unity back in PDM, the leaders were meeting on November 14, 2020. The phrase 'new charter' shows the possible new strategies and rigorous plans of PDM to achieve its cause.

Opposition movement lacks direction: Shibli (The Express Tribune November 9,

The conflicts in PDM have given the government and its ministers a chance to criticize it as this headline manifest the comment of Shibli Faraz. Faraz observes the political movement of PDM as directionless. The political activity of eleven parties is likely to be disturbed if a single party steps back from the set plan and the direction of the movement as a whole is disturbed, to which Shibli Faraz is hinting in this news headline. The phrase 'lacks direction' is used to pin the fault in PDM and declare it directionless. Shibli uses this phrase for the whole PDM movement to clarify that none of these eleven parties can uproot the government.

Opposition's greater game plan' slammed (The Express Tribune November 2,

The political downfall of the opposition movement is indicated in this news headline. The decline and conflicts of PDM are highlighted in multiple newspapers in different ways. This news headline indicates that the notion of Murad Saeed regarding the agenda of opposition. He declares the agenda of PDM as foreign agenda as it is working to uproot a democratic government from Pakistan.

\section{Section B: Theory of Ideologies in News Headlines}

Van Dijk (1995) proclaims that ideologies are the index of thoughts and a social cognition system. The twenty news headlines about Pakistan Democratic Pakistan (PDM) are evaluated using the theory of ideology, which manifests that 
PDM is formed which a specified aim and stimulates specific ideological responses in public by either encouraging them to support the government or to protest against it. The reactions of the public are based on the ideology of PDM, as it is the ideology that shapes the cognitive patterns and course of a society. The above news headlines show how past ideologies are formed and the rapid positive and negative changes they bought to the community. The ideology of PDM to uproot the government and challenge its poor performance has attracted people towards itself and based on this ideology, the Pakistani public took part in rallies, protests and attended meetings and jalsas of PDM. On the other hand, the ideology held by PDM has caused many people to stand and support the government in difficult times.

The ideological square given by Van Dijk (2000) is comprised up of four principles that highlight the ideological differences between US and THEM. The ideological differences are presented subjectively in different mediums by emphasizing the right side of what favour the US and the wrong side of what favors THEM. The CDA analysis and application of Van Dijk's ideological square on the twenty selected headlines about PDM show that government ministers always tend the words which target the unity and agenda of PDM. For example, 'United', 'drama', 'NRO', 'dissolve PDM' etc. are evidence of emphasizing the bad things about PDM and showing it as an incapable, politically disabled and one-sided movement that lacks strength and unity. On the other hand, the opposition leaders show the words that show their unity and strength. The opposition leaders used the terms to show the government's weakness and realize that it is not worthy of governing Pakistan.

\section{Findings}

The data analysis in section A reveals the political framework of PDM, its working plans, proceeding agendas, and criticism on govt. The textual analysis reveals the inner conflicts and clashes among the eleven political parties of PDM. The political opposition movement having a precise aim of derailing the government is not easy to lead and move on. The selected news headlines reveal the political upheavals in the establishment and journey of PDM. Section B of data analysis shows an ideological difference between the political stance and actions of PDM and PTI's government. The ideological square of Van Dijk reveals that PDM is promoting good and neglecting bad about itself while the government is emphasizing good about its policies and hiding the bad aspects of the economy and progress.

\section{Conclusion}

This study aimed to undergo the CDA analysis of the text of randomly selected news headlines about the Pakistan Democratic Movement (PDM). It aimed to highlight the ideology of the PDM, which highlights the negative aspects and incapability of the government. Critical Discourse Analysis (CDA) is the close 
examination of discursive political and power ideologies in linguistic studies. It is the most followed strategy for analyzing political issues and current affairs. The initial step of CDA is to undergo the textual analysis of the text, which involves checking the vocabulary and grammar of the text. The ideological research of the twenty headlines shows that PDM is promoting its ideology and agenda by emphasizing the good side of itself and the wrong side of Imran Khan's rule.

On the other hand, the government is not affected by the political hatred of PDM, and it highlights the adverse impacts of such movements on democracy and its survival. The textual analysis of randomly selected twenty headlines shows that PDM is consistent and firm on getting rid of government by rigorous steps and strategies. The government is also compatible with its view on completing the five years of its rule. PDM declares the government as a failure while the government believes such trivial movements cannot harm it. The purpose of the study was to put forward both narratives and highlight the ideological differences in them. The analysis shows that either it is PDM or the government, both hold ideology before anything else. Furthermore both are ready to go to any extent for completion of its aims. 


\section{References}

Baloch, Mir Shah. \& Peterson, Ellis Hannah. (2020, 0ctober 17). Pakistan's united Opposition protest against Imran Khan's rule. The Guardian. https://amp.theguardian.com/world/2020/oct/16/pakistans-united-oppositionprotests-against-imran-khans-rule

Bilal, H. A. , \& Ahsan, H. M. , (2012). Critical discourse analysis of political TV talk shows of Pakistan media. International Journal of Linguistics. 491), 202-219.

Dijk, V. (1995). Discourse analysis as political analysis. Language and Peace. 10, 47142

Dijk, V. (1998). News as Discourse. New Jersey \& London: Lawrence Earlbaum Associates Publication

Dijk, V. (2000). Ideology and discourse -A Multidisciplinary Introduction. Pompeu Fabra University, Barcelona.

Dissolve PDM after PPP's Decision: (20 January, 2021). The News. https://www.thenews.com.pk/amp/767552-dissolve-pdm-after-ppp-s-decisiondemands-shibli

Fairclough, N. \& Wodak, R. (1997). Critical discourse analysis.' In T. van Dijk (ed.), Discourse Studies: A Multidisciplinary Introduction. Vol. 2. London:

Fairclough, N. (2000). Language and Power. $2^{\text {nd }}$ edition. New York.

Hanif, Haseeb. (2021, December 18). Opposition Staging Drama to get NRO: Murad. The Express Tribune. https://tribune.com.pk/story/2276378/opposition-staging-dramato-get-nro-murad

Jamal Hoti, Muhammad. (2020, December 24). No let-up in the agitation till PTI govt's ouster: PDM. Dawn. https://www.dawn.com/news/1597521/no-let-up-inagitation-till-pti-govts-ouster-pdm

Opposition Movement Lacks Direction: November 21, 2021. The Express Tribune. https://tribune.com.pk/epaper/2020-11-09/3

Pasha, T. (2011). Islamists in the headline: Critical discourse analysis of the representation of the Muslim Brotherhood in Egyptian newspapers. University of Utah, USA.

PDM has its own interests: December 21, 2021.Daily Balochistan Express Quetta. https://bexpress.com.pk/2020/12/pdm-has-its-own-interests-sherani/ 
PDM Playing "reckless" politics with people's safety amidst Covid surge: PM: (November 21, 2021). The Nation. https://nation.com.pk/21-Nov-2020/pdmplaying-reckless-politics-with-people-s-safety-amidst-covid-surge-pm

People won't pay heed to PDM protest plans: PM. January 2, 2021. The Dawn. https://www.dawn.com/news/1599192/people-wont-pay-heed-to-pdm-protestplans-pm

Raza, Syed Irfan. (2021, January 20). PDM takes anti-PTI Protest to ECP Officer. Dawn. https://www.dawn.com/news/1602475

Wasim, Amir. \& Khan, Ifthikhar.A. (2020, September 20). Opposition moot to devise anti-govt strategy today. Dawn. https://www.dawn.com/news/1580646/opposition-moot-to-devise-anti-govtstrategy-today

Wodak, R. and Ludwig, C. (1999). Challenges in a Changing World. Issues in Critical Discourse Analysis. Vienna.

Woodak, R., \& Fairclough, N. (1997). Critical Discourse Analysis. In T. A. van Dijk (Ed). , Discourse as Social Interaction 